\title{
THE A N N A S
}

AND

\section{MAGAZINE OF NATURAL HISTORY.}

\author{
No. 96. FEBRUARY 1845.
}

\begin{abstract}
IX.-Description of some Animals found amongst the Gulf-weed. By HaRry D. S. Goodsir, M.W.S.
\end{abstract}

[With a Plate.]

The animals described in the following communication are chiefly Mollusca and Crustacea, and were all found attached to the Gulf-weed, Fucus natans.

I am indebted to my friend Professor Edward Forbes of King's College, London, and Mr. A. G. Melville, Assistant Demonstrator of Anatomy in the University of Edinburgh, for the opportunity thus afforded me of examining the creatures found in such a habitat. The contents of the bottle received from Prof. E. Forbes were taken between the parallels of $25^{\circ}$ and $36^{\circ}$ north, and in about $40^{\circ}$ west long.; and the specimens received from Mr. Melville were all taken about $40^{\circ}$ north lat. during the course of one day's sailing. It will be observed that the animals from both of the above districts are generically and in most instances specifically similar.

Nautilograpsus minutus, Edwards. Pl. VII. fig. 1.

Inter-orbital space slightly hollowed in the mesial line, serrated very minutely, the teeth being only seen with a magnifier. Internal orbital angles rounded, external projecting forward in the form of spines and very acute ; lateral edge of the carapace armed with a single blunt tooth shortly behind the external orbital angle.

Description.-The whole body of a straw-yellow, with shades of a reddish blue colour on the carapace; tips of the eyes black.

Carapace almost square, the anterior or inter-orbital space projecting, the posterior part of the lateral edges contracting slightly, the latero-posterior edges of considerable length, and the posterior hardly so extended as the anterior. Dorsal surface of the carapace shining, slightly convex, and with the sculpturing hardly perceptible, but very delicately grooved transversely Ann.\& Mag. N. Hist. Vol. xv, 
with punctured lines running almost parallel to one another. Ambulatory legs of considerable length; the anterior pair large, the arm extending beyond the lateral edge of the carapace, and having its internal edge very much depressed and thinned, at the anterior angle of which are several strong spines; the remaining legs are all depressed, with the edges of the last three joints armed with long, thick-set hairs, and especially the superior edges. The internal antennæ consist of four segments, the last being multiarticulate, and a strong articulated spine arises from the internal edge of the third articulation near its distal extremity. The external pair of antennæ arise from the internal angles of the orbit, are multiarticulate and very minute. The external foot-jaws are large, but have their internal edges so formed as to leave a lozenge-shaped space between them. The abdomen in the male of this species is narrow and of a triangular shape; that of the female large, rounded, and covering almost all the lower surface of the body. It appears to have been found in great numbers both by Mr. Williams and Mr. Melville.

\section{Hippolyte ensiferus. Pl. VII. fig. 2.}

$H$. with one short tooth projecting forwards from the base of the rostrum; rostrum slightly curved upward with four or five spines at the tip, the third of which from the dorsum is longest. Peduncular scale of external antennæ not so long as the rostrum almost by one-third. External foot-jaws not so long as the peduncle of the external antennæ; with the terminal joint flattened, serrated at the apex and on its internal edge.

Description. - The whole animal about 1 inch in length, of an ochrey yellow colour except the tips of the eyes, which are black. The internal antennæ with the peduncle 3-jointed; the scale of the external pair very thin and narrowed at the tip, which is also bifurcated. The external foot-jaws have the external edge of the last joint smooth and rather thickened. The first pair of thoracic legs are short, thick, smooth and didactyle; those of the second pair are long, filiform, spined, and also didactyle; the third articulation is very slender. The last three pairs of legs are much longer than any of the preceding, filiform and spined. The middle plate of the tail not so long as the second, armed with two pairs of spines at the tip.

Found in considerable abundance between the parallels of $25^{\circ}$ and $30^{\circ}$ north, and $4^{\circ}$ west long., by Mr. Williams. Almost every specimen infested with Bopyrus squillarum.

\section{Palamon natator. Pl. VII. fig. 3.}

$\boldsymbol{P}$. with the rostrum lanceform, having eleven or twelve large distinct spines on its superior edge, and two small rather indi- 
stinct ones on its inferior edge near the tip. Two spines on each side of the carapace near or on the anterior edge. Middle plate of the tail with three obsolete spines on each side and two long spines from the extremity.

Description.-The whole animal of a yellow colour; rather more than an inch in length and very robust. Rostrum about the same length as the peduncular scales of external antennæ, lanceolate, being rounded and narrowed at the base and dilated. near the extremity before ending in a point. The peduncular portion of the superior antennæ 4-jointed, the basal joint being large and hollowed out superiorly for the reception of the eyes; each of the segments of the peduncle end externally and anteriorly in a spine which projects forwards and outwards. The outermost of the three terminal filaments is the thickest. The peduncular scale of the external antennæ does not terminate in a point, but is obliquely truncated; the terminal filament is longer than those of the superior antennæ. First pair of legs very slender, reaching a little beyond the peduncle of external antennæ, didactyle. Second pair much stronger, and although the first four joints are delicate, the hand is large and ovate, didactyle; claws slender and almost straight. The last pair of legs slender.

\section{Amphitöe pelagica. Pl. VII. fig. 4.}

$A$. with peduncle of superior antennæ about half the length of the inferior antennæ, being almost the same length as the first three joints of the peduncle of the lower antennæ. First pair of legs small, second pair with the wrist very much enlarged, and the claw sickle-shaped and moveable, inferior edge having a small tooth with a slight notch on either side of it near the distal extremity; claw as long as the wrist and tapering very gradually to a point.

\section{Bopyrus squillarum. Pl. VII. figs. 5, 6, 7, 8, 9, 10, 11.}

$B$. with posterior edge of last abdominal segment perfect.

Description.-Male minute, about 1 line in length or hardly so long, linear. Head small, and about half as long as its greatest breadth. First thoracic joint larger than any of the succeeding. Ambulatory legs very short and chelate. Female broad, flattened and pyriform, very much contracted posteriorly and dilated anteriorly. Young almost globular. From beneath carapace of Hippolyte ensiferus.

\section{Anatifa sulcata. Pl. VII. fig. 13.}

The peduncle of this Anatifa is so short as not to be seen without separating the animal from its attachment. The shape is triangular, and the peduncular extremity of the animal is 
slightly concave, with the posterior edges of the latero-peduncular divisions serrated; the posterior and abdominal angle of this part of the shell is incurvated and pointed, and its external surface is deeply sulcated, the sulci all radiating from the posterior abdominal angle to the dorsal edge of the division, where they form small but very distinct serrations. Dorsal division of the shell smooth, extending almost the whole length of the dorsum, and reflected upon the posterior dorsal angles of the latero-peduncular division. A small obsolete tooth may be observed upon the dorsal edge near its anterior extremity. The antero-lateral are much smaller than the peduncular divisions of the shell, and are also sulcated, the sulci radiating from the anterior point towards the abdominal edge : the ridges formed by these sulci are armed in both divisions with minute teeth, the points of which in the peduncular portion all project towards the dorsum, those in the anterior towards the abdomen. Attached to a portion of Fucus natans.

The species now described differs in some points from the figure given by Quoy and Gaimard in the 'Voyage de l'Astrolabe,' which beautiful work I have been able to see through the kindness of Mr. Grut; I thought it unnecessary however to give another specific name.

Several specimens of Scyllaa pelagica were in the bottle, and the spawn (Pl. VII. fig. 14) of this animal was attached in several places to the Fucus in rather irregular coils; the central extremity adhered to a stem of the Fucus, the succeeding parts surrounding it in coils, the external extremity being attached in the same manner as the central one.

\section{EXPLANATION OF PLATE VII.}

Fig. 1. Nautilograpsus minutus, nat. size.

Fig. 2. Hippolyte ensiferus, mag. three times.

Fig. 3. Palamon natator, mag. twice.

Fig. 4. Amphitöe pelagica, enlarged.

Fig. 5. Bopyrus squillarum, female, magnified.

Fig. 6. - young.

Fig. 7. $\longrightarrow$, male.

Fig. 8. The abdominal surface of the head of male Bopyrus.

Fig. 9. One of the ambulatory legs of male Bopyrus.

Fig. 10. One of the ambulatory legs of female.

Fig. 11. Last abdominal segment of female Bopyrus, showing the entire segment.

Fig. 12. Drawing of an ovum, a cluster of which were attached to the Fucus. Fig. 13. Anatifa sulcata, magnified, attached to a portion of the Gulf-weed. Fig. 14. Spawn of Scyllaa pelagica. 


\section{$2 \mathrm{BHL}$ Biodiversity Heritage Library}

Goodsir, Harry D. S. 1845. "IX.-Description of some animals found amongst the Gulf-weed." The Annals and magazine of natural history; zoology, botany, and geology 15, 73-76. https://doi.org/10.1080/037454809495259.

View This Item Online: https://www.biodiversitylibrary.org/item/19398

DOI: https://doi.org/10.1080/037454809495259

Permalink: https://www.biodiversitylibrary.org/partpdf/23836

\section{Holding Institution}

Natural History Museum Library, London

\section{Sponsored by}

Natural History Museum Library, London

\section{Copyright \& Reuse}

Copyright Status: Public domain. The BHL considers that this work is no longer under copyright protection.

This document was created from content at the Biodiversity Heritage Library, the world's largest open access digital library for biodiversity literature and archives. Visit BHL at https://www.biodiversitylibrary.org. 